\title{
ANALISA SIFAT FISIK DAN SIFAT KIMIA MATERIAL BATANG KULIT POHON SAGU (CORTEX METROXYLON SAGO) SEBAGAI MATERIAL ALTERNATIF BANGUNAN KAPAL
}

\author{
Fella Gaspersz ${ }^{1}$, Andjela Sahupala, H. C. Ririmasse \\ E-mail : ${ }^{1}$ fella_ambon@yahoo.com \\ Jurusan Teknik Perkapalan Fakultas Teknik Universitas Pattimura
}

\begin{abstract}
Material kayu banyak digunakan dalam pembuatan kapal kayu serta bagian interior kapal baja atau kapal fiberglass. Material kayu yang digunakan untuk konstruksi kapal haruslah memenuhi syarat kualifikasi (Biro Klasifikasi Indonesia) dengan kategori kelas kuat dan kelas awet sehingga dapat digunakan pada bagian konstruksi serata badan kapal. Dewasa ini pemakaian kebutuhan kayu untuk keperluan struktur dalam jumlah besar dengan kualitas tinggi semakin sulit diperoleh. Hal ini menyebabkan harga kayu untuk keperluan material kapal sangat tinggi. Sehingga diperlukan material alternatif dalam membangun kapal kayu. Material Batang Kulit Pohon Sagu sejak jaman primitif telah digunakan pada kapal yang sederhana atau bagian interior konstruksi kapal namun material ini belum dikaji secara teknik. Potensi Pohon Sagu oleh masyarakat lokal masih sebatas memanfaatkan pati sagunya sebagai bahan makan pokok dan daunnya sebagai atap rumah, sedangkan Batang Kulit Pohon Sagu tidak dimanfaatkan dan dibiarkan sebagai limbah hasil pengolahan sagu. Penelitian ini bertujuan untuk menentukan kelas awet dan kelas kuat material Batang Kulit Pohon Sagu berdasarkan analisa sifat kimia dan sifat mekanis material Limbah Batang Kulit Pohon Sagu. Hasil penelitian diperoleh nilai rata-rata kadar air berkisar antara 5,13\% - 6,89\%, Rata-rata Berat Jenis material Limbah Batang Kulit Pohon Sagu berkisar antara $0,86 \mathrm{~kg} / \mathrm{m}^{3}$.Pengujian tarik (Tensile Test) dan pengujian Tekan (Compressive Test) mengunakan pengujian standard ASTM D 3039/3039 M dan ASTM D 3410/3410M. Kekuatan tarik rata-rata dari kelima jenis Pohon Sagu yang tersebar di Provinsi Maluku adalah $1019 \mathrm{~kg} / \mathrm{cm}^{2}-1101,29 \mathrm{~kg} / \mathrm{cm}^{2}$, kekuatan tekan rata-rata adalah $458,87 \mathrm{~kg} / \mathrm{cm}^{2}-520,05 \mathrm{~kg} / \mathrm{cm}^{2}$. Dengan demikian material Batang Kulit Pohon Sagu masuk dalam kualifikasi Kelas Kuat II menurut standard BKI untuk Kapal Kayu.Penentuankelas awet yang dilakukan dengan menggunakan prosedur standar SNI 01-7207-2006 tentang uji ketahanan kayu dan produk kayu terhadap organisme perusak kayu dilaut dengan rata-rata intesitas serangan sebesar $16 \%$ Namun kelemahan dari material ini adalah ketebalan Batang Kulit Pohon Sagu yang berkisar antara $1 \mathrm{~cm}-2 \mathrm{~cm}$ sehingga harus dilakukan rekayasa model untuk mendapatkan bentuk profil sesuai dengan ketebalan profil pada bangunan kapal.
\end{abstract}

Kata kunci: Limbah Batang Kulit Pohon Sagu, Material Alternatif

\section{PENDAHULUAN}

Kapal merupakan suatu konstruksi enginering yan dibutuhkan untuk melayani berbagai perkerjaan di laut atau berbagai daerah perairan. Kapal dapat ditemui dalam berbagai bentuk, ukuran dan tipe dari yang sangat sederhana sampai yang moderen. Sejarah perkapalan berawal dari aplikasi kapal dalam bentuk primitif yang dikembangkan oleh sukusuku primitif di berbagai kawasan di dunia. Dalam perkembangannya kapal mengalami perkembangan yang pesat dalam berbagai aspek. Salah satu aspek yang cukup menonjol adalah material kapal. (Tarkono, 2006)

Untuk beberapa tipe kapal dan kebutuhan konstruksi kapal maka pemanfaatan material lokal sangatlah membantu untuk menghindari penggunaan material import. Material BatangKulit Pohon Sagu (Cortex Metroxcylon
Sago) telah digunakan oleh masyarakat Maluku dan kawasan Pasifik sejak jaman primitif sebagai material utama alat penyeberangan antar sungai. Bentuk kapal yang digunakan masih sangat sederhana yaitu sampan angkutan sungai/danau dalam ukuran kapal yang terbatas. Material ini cukup tahan terhadap kondisi perairan. Batang Kulit Pohon Sagu ini juga telah dipakai untuk berbagai keperluan interior konstruksi lainnya. Akan tetapi pada waktu belakangan ini, material Batang Kulit Pohon Sagu tidak dipakai lagi. Sementara penggunaan material kayu untuk kapal belakangan ini sangat terbatas akibat kelangkaan material kayu dengan kualifikasi penggunaan untuk kapal.

Penelitian ini dilakukan untuk menganalisa sifat fisik dan mekanis dari material Batang Kulit Pohon Sagu untuk menentukan kelas awet dan kelas kuat material Batang Kulit Pohon Sagu 
sesuai standar Biro Klasifikasi Indonesia tentang Konstruksi Kapal Kayu. Sepisimen yang digunakan dalam penelitian ini adalah kelima jenis pohon Sagu yang terdapat di ProvinsiMaluku, dengan memperhatikanletak posisi sampel pada batang pohon. Dalam penelitian ini diteliti sifat-sifat fisik dan mekanis Batang Kulit Pohon Sagu untuk menentukan kelas awet serta kelas kuat Batang Kulit Pohon Sagu, serta pembuatan blue-print sampel Batang Kulit Pohon Sagu untuk proses penelitian pada tahadapan selanjutnya.

\section{KAJIAN TEORI DAN METODE}

Pada penelitian ini dilakukan pengujian terhadap material Batang Kulit Pohon Sagu untuk menentukan kelas awet dan kelas kuatnya berdasarkan standarisasi dari Biro Klasifikasi Indonesia tentang Kapal Kayu Tahun 1996. Di awali dengan penentuan kadar air dan berat jenis material Limbah Batang Kulit Pohon Sagu. Selanjutnyadilakukan penentuan kelas awet yang dilakukan dengan menggunakan prosedur standar SNI 01-7207-2006 tentang uji ketahanan kayu dan produk kayu terhadap organisme perusak kayu dilaut. Sedangkan penentuan kelas kuat dilakukan pengujian tarik dan tekan menggunakan pengujian laboratorium menggunakan universal testing machine (UTM) pada UPT Politeknik Negeri Ambon. Untuk pengujian tarik dan pengujian tekan Limbah Batang Kulit Pohon Sagu dibentuk menjadi spesimen. Adapun standard yang digunakan untuk pengujian ini adalah ASTM 2004 (3). Pengujian tekan menggunakan ASTM D3410/3410M. Sedangkan pengujian tarik menggunakan ASTM D3039/3039M. Ukuran spesimen uji tarik dan uji tekan sesuai dengan gambar 2 dan gambar 3. Spesimen uji tarik dibuat dengan ukuran $250 \times 2 \times 2,5 \mathrm{~mm}$. Sedangkan ukuran uji tekan dibuat dengan ukuran 150 x 2,5 x 2,5 mm. Pada spesimen uji tarik dibuat tirus bagian tengah sehingga tebalnya menjadi $7 \mathrm{~mm}$.

Limbah Material Batang Kulit Pohon Sagu dibentuk spesimen untuk pengujian tekan dan pengujian tarik. Batang Kulit Pohon Sagu memiliki ketebalan yang bervariasi antara $1-2$ $\mathrm{cm}$ sesuai dengan letaknya pada pohon. Dalam penelitian ini material Limbah Batang Kulit Pohon Sagu yang digunakan sebagai spesimen, diambil sesuai dengan lokasinya pada pohon Sagu (Bagian pangkal, bagian tengah dan bagian ujung pohon Sagu)

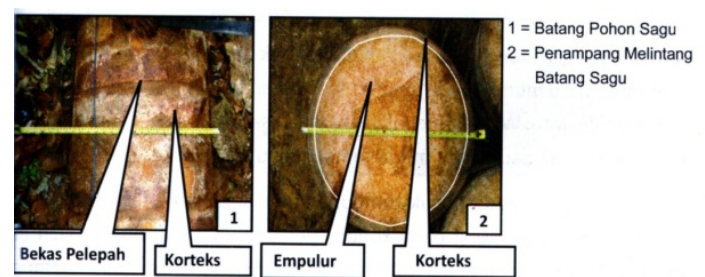

Gambar 1. Batang Kulit Pohon Sagu

Untuk menentukan kadar air Limbah Batang Kulit Pohon Sagu dilakukan sesuai dengan standar ISO 22157-1-2004 dengan benda uji berukuran $460 \mathrm{x}$ $25 \times 25 \mathrm{~mm}$. Kadar air material Batang Kulit Pohon Sagu dihitung degan rumus :

Di mana :

$$
M c=\frac{m-m o}{m o} \times 100 \%
$$

Mc : Kadar air (\%)

$\mathrm{m}$ : massa benda uji sebelum kering (gram)

mo : massa benda uji setelah kering (gram)

Untuk pengujian berat jenis material Limbah Batang Kulit Pohon Sagu dilakukan dengan menggunakan pengujian Uji Kering Udara. Di mana material Batang Kulit Pohon Sagu dibentuk menjadi spesimen dengan ukuran $5 \mathrm{~mm}$ x $5 \mathrm{~mm}$. Spesimen tersebut ditimbang kemudian dikeringkan dengan suhu oven $180^{\circ} \mathrm{C}$.

\section{HASIL DAN PEMBAHASAN}

\section{A. Kadar Air.}

Kadar air dari material Batang Kulit Pohon Sagu berdasarkan hasil penelitian untuk masingmasing jenis pohon sagu adalah sebagai berikut:

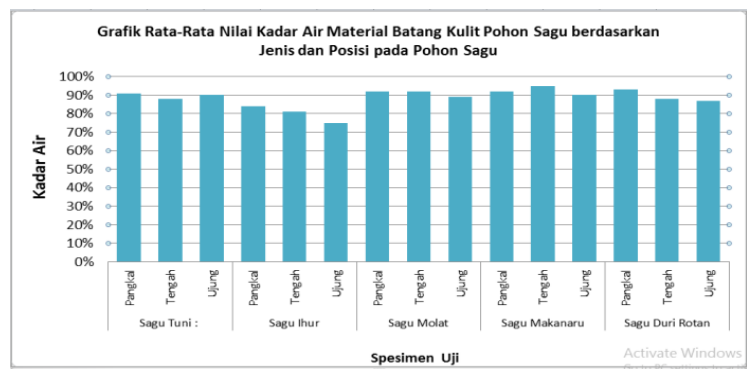

Gambar 2. Grafik Rata-Rata Nilai Kadar Air

Dengan nilai rata-rata kadar air berkisar antara $5,13 \%-6,89 \%$.

\section{B. Berat Jenis}

Berat Jenis material Limbah Batang Kulit Pohon Sagu berdasarkan hasil penelitian adalah sebagai berikut : 


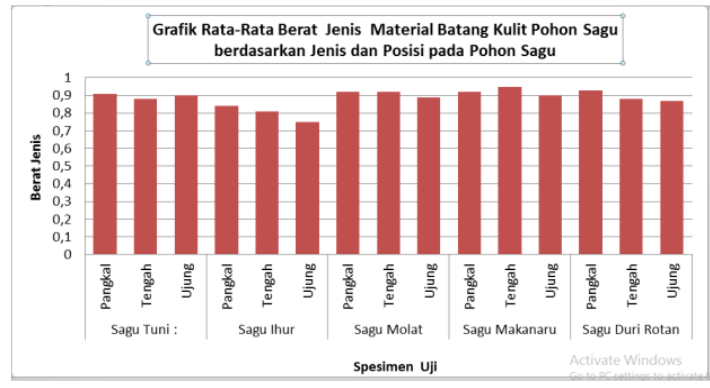

Gambar 3. Grafik Rata-Rata Berat Jenis

Rata-rata Berat Jenis material Limbah Batang Kulit Pohon Sagu berkisar antara $0,75 \mathrm{~kg} / \mathrm{m}^{3}-$ $0,95 \mathrm{~kg} / \mathrm{m}^{3}$. Berdasarkan peraturan Biro Klasifikasi Indonesia tentang Kapal Kayu Tahun 1996, material Batang Kulit Pohon Sagu termasuk dalam Kelas Kuat II.

\section{Analisa Kelas Kuat}

Setelah dilakukan pengjuian tekan dan tarik didapatkan hasil pembebanan maksimum masing-masing spesimen uji kemudian dibagi dengan luasan spesimen uji sehingga diperoleh kekuatan tarik dan kekuatan tekan.

Dengan menggunakan rumus berikut :

$$
P=\sigma \times A
$$

Di mana :

$\sigma=$ Kuat tarik atau Kuat tekan $\left(\mathrm{KN} / \mathrm{mm}^{2)}\right.$

$\mathrm{P}=$ Beban maksimum $(\mathrm{KN})$

$\mathrm{A}=$ Luas penampang spesimen.

Tegangan maksim tiap spesimen dihitung menggunakan rumus diatas kemudian dibuat table seperti table 1. Karena setiap pengujian tarik dan tekan terdapat 3 spesimen untuk masing-masing bagian sehingga nilai kuat tekan dan kuat tarik diambil rata-rata.
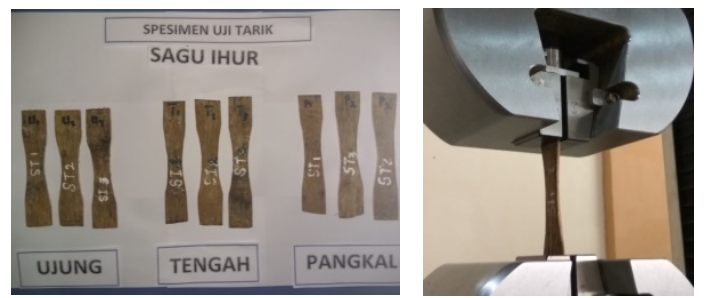

Gambar 4. Spesimen Uji Tarik

Setelah dilakukan perhitungan, maka hasilnya adalah sebagai berikut :
Tabel.1a.Kuat Tarik Rata-Rata Batang Kulit Pohon Sagu

\begin{tabular}{|c|c|c|c|c|}
\hline \multirow{2}{*}{$\begin{array}{l}\text { Jenis } \\
\text { Pohon } \\
\text { Sagu }\end{array}$} & \multirow{2}{*}{$\begin{array}{l}\text { Posisi } \\
\text { Spesimen }\end{array}$} & $\mathrm{P}_{\mathrm{Max}}$ & A & $\sigma_{\operatorname{Max}}$ \\
\hline & & $(\mathrm{N})$ & $\left(\mathrm{mm}^{2}\right)$ & $\begin{array}{c}\mathrm{N} / \\
\mathrm{mm}^{2}\end{array}$ \\
\hline \multirow{3}{*}{ Sagu Tuni : } & Pangkal & 9630 & 89,01 & 108 \\
\hline & Tengah & 9410 & 93,81 & 100 \\
\hline & Ujung & 9534 & 90,78 & 105 \\
\hline \multirow{3}{*}{ Sagu Ihur } & Pangkal & 9745 & 91,58 & 106 \\
\hline & Tengah & 9669 & 92,05 & 105 \\
\hline & Ujung & 9678 & 93,01 & 104 \\
\hline \multirow{3}{*}{ Sagu Molat } & Pangkal & 9567 & 90,02 & 106 \\
\hline & Tengah & 9781 & 93,45 & 105 \\
\hline & Ujung & 9345 & 93,11 & 100 \\
\hline \multirow{3}{*}{$\begin{array}{l}\text { Sagu } \\
\text { Makanaru }\end{array}$} & Pangkal & 9670 & 94,26 & 103 \\
\hline & Tengah & 8400 & 80,36 & 105 \\
\hline & Ujung & 8310 & 80,87 & 103 \\
\hline \multirow{3}{*}{$\begin{array}{l}\text { Sagu Duri } \\
\text { Rotan }\end{array}$} & Pangkal & 8560 & 79 & 108 \\
\hline & Tengah & 8257 & 80,09 & 103 \\
\hline & Ujung & 8067 & 79,09 & 102 \\
\hline
\end{tabular}

Tabel 1. Menunjukan perhitungan kuat tarik ratarata Batang Kulit Pohon Sagu dari masing-masing jenis pohon sagu sesuai dengan letak/posisinya pada pohon. Luas penampang antar spesimen berbeda disebabkan karena perbedaan ketebalan Batang Kulit Pohon Sagu.

Pembagian antara beban tarik maksimum dengan luas penampang menghasilkan kuat tekan. Berdasarkan Tabel 1. kuat tarik maksimum Batang Kulit Pohon Sagu terdapat pada bagian Pangkal yang berkisar antara $100 \mathrm{~N} / \mathrm{mm}^{2}-108$ $\mathrm{N} / \mathrm{mm}^{2}$ atau $1019 \mathrm{~kg} / \mathrm{cm}^{2}-1101,29 \mathrm{~kg} / \mathrm{cm}^{2}$.

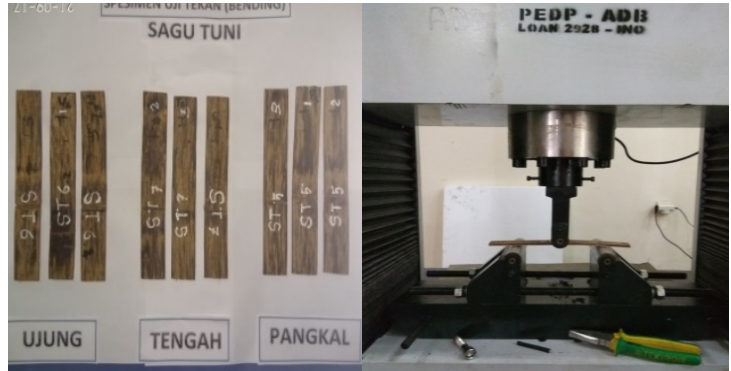

Gambar 5. SpesimenUji Tekan

Kuat tekan masing-masing spesimen didapat dengan membagi beban tekan maksimum dengan luas penampang spesimem. Setelah dilakukan perhitungan hasilnya adalah sebagai berikut : 
Tabel 1b. Kuat Tekan rata-rata Sagu

\begin{tabular}{|c|c|c|c|c|}
\hline \multirow{2}{*}{$\begin{array}{l}\text { Jenis } \\
\text { Pohon } \\
\text { Sagu }\end{array}$} & \multirow{2}{*}{$\begin{array}{l}\text { Posisi } \\
\text { Spesimen }\end{array}$} & $P_{\text {Max }}$ & A & $\sigma_{\operatorname{Max}}$ \\
\hline & & $(\mathrm{N})$ & $\left(\mathrm{mm}^{2}\right)$ & $\mathrm{N} / \mathrm{mm}^{2}$ \\
\hline \multirow{3}{*}{$\begin{array}{l}\text { Sagu } \\
\text { Tuni : }\end{array}$} & Pangkal & 9000 & 180,66 & 50 \\
\hline & Tengah & 9000 & 189,63 & 47 \\
\hline & Ujung & 8978 & 179,99 & 50 \\
\hline \multirow{3}{*}{$\begin{array}{l}\text { Sagu } \\
\text { Ihur }\end{array}$} & Pangkal & 9210 & 182,33 & 51 \\
\hline & Tengah & 9012 & 180,24 & 50 \\
\hline & Ujung & 9009 & 180,89 & 50 \\
\hline \multirow{3}{*}{$\begin{array}{l}\text { Sagu } \\
\text { Molat }\end{array}$} & Pangkal & 8678 & 179,89 & 48 \\
\hline & Tengah & 8999 & 180,03 & 50 \\
\hline & Ujung & 8745 & 178,56 & 49 \\
\hline \multirow{3}{*}{$\begin{array}{l}\text { Sagu } \\
\text { Makan } \\
\text { aru }\end{array}$} & Pangkal & 8545 & 175,23 & 49 \\
\hline & Tengah & 8400 & 174,33 & 48 \\
\hline & Ujung & 8310 & 170,22 & 49 \\
\hline \multirow{3}{*}{$\begin{array}{c}\text { Sagu } \\
\text { Duri } \\
\text { Rotan }\end{array}$} & Pangkal & 8560 & 173,89 & 49 \\
\hline & Tengah & 8257 & 170,99 & 48 \\
\hline & Ujung & 8067 & 179,82 & 45 \\
\hline
\end{tabular}

Tabel 1b. Menunjukan perhitungan kuat tekan rata-rata Batang Kulit Pohon Sagu dari masingmasing jenis pohon sagu sesuai dengan letak/posisinya pada pohon. Luas penampang antar spesimen berbeda disebabkan karena perbedaan ketebalan Batang Kulit Pohon Sagu. Pembagian antara beban tarik maksimum dengan luas penampang menghasilkan kuat tekan. Berdasarkan Tabel 1. kuat tekan maksimum Batang Kulit Pohon Sagu terdapat pada bagian Pangkal yang berkisar antara $45-51 \mathrm{~N} / \mathrm{mm}^{2}$ atau $458,87 \mathrm{~kg} / \mathrm{cm}^{2}-520,05 \mathrm{~kg} / \mathrm{cm}^{2}$.

\section{Analisa Kelas Awet}

Lokasi penelitian ketahanan limbah Batang Kulit Pohon Sagu terhadap penggerek di laut, dilakukan di perairan Teluk Ambon Bagian Dalam (Perairan Tanjung MarthaFons). Perairantersebutmempunyaisalinitassekitar2831 psu dan suhu sekitar $28-29{ }^{\circ} \mathrm{C}$, dengan $\mathrm{PH}$ berkisar antara $7-8,7$.

Material Batang Kulit Pohon Sagu dari kelima jenis Pohon Sagu dibuat contoh uji berukuran $2,5 \mathrm{~cm} \times 5,0 \mathrm{~cm} \times 30 \mathrm{~cm}$.

Pada bagian tengah permukaan terlebar dibuat lubang dengan diameter $1,5 \mathrm{~cm}$. Contoh bahan uji diikat satu sama lain (direnteng) melalui lubang dengan tali plastik, diantara contoh uji dengan yang lain diberi sekat dengan selang plastic dan dibuat rakit seperti pada Gambar 6.

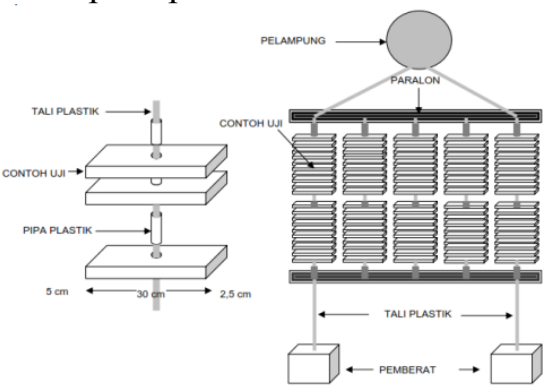

Gambar6 Ukuran Contoh Bahan Uji dan

Susunan Rakit yang Dipasang di Laut

Rakit dipasang dilaut secara vertical dan setelah 7 bulan diambil untuk diamati intensitas serangan penggerek. Untuk menilai intensitas serangan pada contoh uji, dilakukan dengan membelah bagian tengah permukaan terkecil menjadi dua bagian yang sama.

Hasil Pengujian dengan perendaman dilaut selama tujuh bulan adalah sebagai berikut:

Tabel 2 Hasil Pengujian untuk ketahanan terhadap hewan penggerek di Laut selama 6 bulan

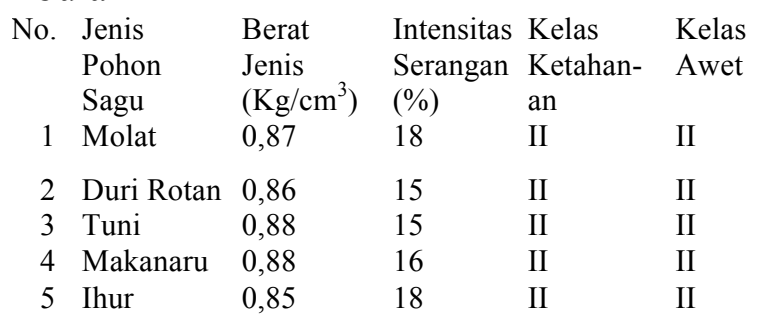

\section{E. Perbandingan Hasil Pengujian Dengan Standard Kapal Kayu dari Biro Klasifikasi Indonesia (BKI)}

Menurut BKI dalam Buku Peraturan onstruksi Dan Kapal Laut (Kapal Kayu) dijelaskan bahwa untuk konstruksi yang penting dalam kapal kayu harus menggunakan kayu dengan mutu minimum Kelas Kuat II dengan perincian seperti tabel berikut : 
Tabel 3. Klasifikasi Kelas Kuat Kayu berdasarkan Biro Klasifikasi Indonesia (Kapal Kayu) 1996.

\begin{tabular}{|l|l|l|l|}
\hline $\begin{array}{l}\text { Kelas } \\
\text { Kuat }\end{array}$ & $\begin{array}{l}\text { Berat Jenis } \\
\text { Kering } \\
\left(\mathrm{Kg} / \mathrm{m}^{3}\right)\end{array}$ & $\begin{array}{l}\text { Keteguhan } \\
\text { Lentur } \\
\text { Mutlak } \\
\left(\mathrm{Kg} / \mathrm{cm}^{2}\right)\end{array}$ & $\begin{array}{l}\text { Ketuguhan } \\
\text { Tekan } \\
\text { Mutlak } \\
\left(\mathrm{Kg} / \mathrm{cm}^{2}\right)\end{array}$ \\
\hline I & $\geq 0,9$ & $\geq 1100$ & $\leq 650$ \\
\hline II & $0,90-0,60$ & $1100-725$ & $650-425$ \\
\hline III & $0,60-0,40$ & $725-500$ & $425-300$ \\
\hline IV & $0,40-0,30$ & $500-260$ & $300-215$ \\
\hline V & $\leq 0,30$ & $\leq 360$ & $\leq 215$ \\
\hline
\end{tabular}

Sumber : Biro Klasifikasi Indonesia 1996

Berdasarkan hasil pengujian maka yang dilakukan maka material Batang Kulit Pohon Sagu termasuk dalam kelas awet II menurut Standard BKI

Tabel 4. Klasifikasi Kelas Awet berdasarkan Biro Klasifikasi Indonesia (Kapal Kayu) 1996

\begin{tabular}{|l|l|l|}
\hline $\begin{array}{l}\text { Kelas } \\
\text { Awet }\end{array}$ & $\begin{array}{l}\text { Intensitas } \\
\text { Serangan (\%) }\end{array}$ & Ketahanan \\
\hline I & $<7$ & Sangat Tahan \\
\hline II & $7-27$ & Tahan \\
\hline III & $27,1-55$ & Agak Tahan \\
\hline IV & $55,1-80$ & Tidak Tahan \\
\hline V & $>80$ & $\begin{array}{l}\text { Sangat Tidak } \\
\text { Tahan }\end{array}$ \\
\hline
\end{tabular}

\section{KESIMPULAN}

Kesimpulan yang dapat diambil dari penelitian ini adalah sebagai berikut:

1. Nilai rata-rata kadar air berkisar dari kelima jenis material Limbah Batang Kulit Pohon Sagu antara 5,13\% - 6,89\%.

2. Rata-rata Berat Jenis material kelimaLimbah Batang Kulit Pohon Sagu berkisar antara 0,86 $\mathrm{kg} / \mathrm{m}^{3}$ memenuhi peraturan Biro Klasifikasi Indonesia tentang Kapal Kayu Tahun 1996, material Batang Kulit Pohon Sagu termasuk dalam Kelas Kuat II

3. Berdasarkan perhitungan nilai kuat tekan material adalah $458,87 \mathrm{~kg} / \mathrm{cm}^{2}-520,05 \mathrm{~kg} / \mathrm{cm}^{2}$ memenuhi klasifikasi kelas Kuat II berdasarkan Peraturan BKI Kapal Kayu 1996. Sehingga Material Batang Kulit Pohon Sagu layak digunakan sebagai material kapal kayu dalam pembangunan kapal kayu.

4. Berdasarkan perhitungan nilai kuat tarik material adalah $1019 \mathrm{~kg} / \mathrm{cm}^{2}-1101,29 \mathrm{~kg} / \mathrm{cm}^{2}$ memenuhi klasifikasi kelas Kuat II berdasarkan Peraturan BKI Kapal Kayu 1996. Sehingga Material Batang Kulit Pohon Sagu layak digunakan sebagai material kapal kayu dalam pembangunan kapal kayu.

5. Berdasarkan intensitas terhadap ketahanan seranngan hewan pengerak di laut, memenuhi Klasifikasi Kelas Awet II menurut Peraturan BKI Kapal Kayu 1996, dengan rata-rata intensitas serangan sebesar $16 \%$

\section{DAFTAR PUSTAKA}

Biro Klasifikasi Indonesia, Buku Peraturan Klasifikasi Dan Konstruksi Kapal Laut, Peraturan Kapal Kayu, 1996

Badan Standarisasi Nasional (BSN), 1999. Standard Nasional Indonesia (SNI) SNI7207:2014. Uji Ketahanan Kayu Terhadap Organisme Perusak Kayu.Badan Standarisasi Nasional. Jakarta

Kembara Rizal Ramadhan, Heri Supomo. 2013. Study Penggunaan Bambu Sebagai Material Alternatif Pembuatan Kapal Kayu dengan Motode Wooden Ship Planking System, Jurnal Teknik POMITS Vol 2, No 1 (2013), ITS, Surabaya

Louhenapessy, J. E, dkk, 2010. Sagu Harapan Dan Tantangan, PT. Bumi Aksara, Jakarta

Martawijaya A, Kartasujana I, Kosasi K, Soewanda AP., 1981. Atlas Kayu Indonesia. Jilid I. Bogor: Badan Penelitian dan Pengembangan Hasil Hutan

Pasaribu, B.P. 1987, Material Kayu Utuh dan Kayu Sambungan untuk Konstruksi Kapal Penangkap Ikan. Buletin PSP Volume I No.2. Bogor: Departemen Pemanfaatan Sumberdaya Perikanan, Fakultas Perikanan dan Ilmu Kelautan, Institut Pertanian Bogor. 